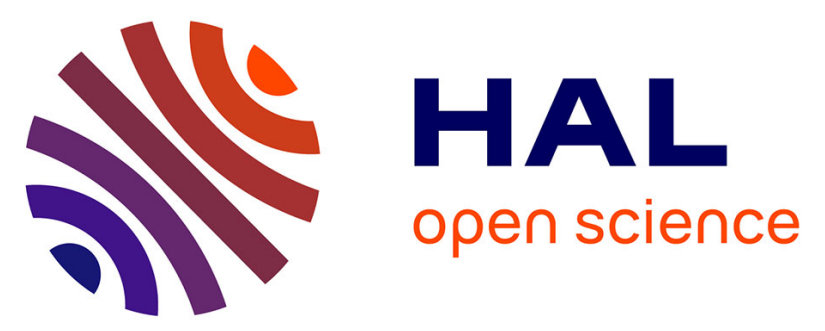

\title{
Research on the Allocation in the Complex Adaptive System of Agricultural Land and Water Resources of the Sanjiang Plain
}

Qiang Fu, Tienan Li, Tianxiao Li

\section{To cite this version:}

Qiang Fu, Tienan Li, Tianxiao Li. Research on the Allocation in the Complex Adaptive System of Agricultural Land and Water Resources of the Sanjiang Plain. 8th International Conference on Computer and Computing Technologies in Agriculture (CCTA), Sep 2014, Beijing, China. pp.99-106, 10.1007/978-3-319-19620-6_13 . hal-01420220

\section{HAL Id: hal-01420220 \\ https://hal.inria.fr/hal-01420220}

Submitted on 20 Dec 2016

HAL is a multi-disciplinary open access archive for the deposit and dissemination of scientific research documents, whether they are published or not. The documents may come from teaching and research institutions in France or abroad, or from public or private research centers.
L'archive ouverte pluridisciplinaire HAL, est destinée au dépôt et à la diffusion de documents scientifiques de niveau recherche, publiés ou non, émanant des établissements d'enseignement et de recherche français ou étrangers, des laboratoires publics ou privés. 


\title{
Research on the Allocation in the Complex Adaptive System of Agricultural Land and Water Resources of the Sanjiang Plain
}

\author{
Qiang $\mathrm{Fu}^{1, \mathrm{a}}$, Tienan $\mathrm{Li}^{1, \mathrm{~b}}$, Tianxiao $\mathrm{Li}^{1, \mathrm{c}}$ \\ ${ }^{1}$ School of Water Conservancy \&Civil Engineering, Northeast Agricultural University, Harbin \\ 150030,China; ${ }^{2}$ Institute of Food Science and Engineering, Wuhan Polytechnic University, \\ Harbin 150030, China; \\ afuqiang0629@126.com, ${ }^{\mathrm{b}} 719287576 @$ qq.com, ${ }^{c}$ litianxiao.888@163.com
}

\begin{abstract}
As for the improper water and land use structure and difficulty in bringing the system into maximum performance, this research takes the Sanjiang Branch of Heilongjiang Land Reclamation Bureau as an example and uses the concept of complex adaptive system to build an allocation model of the complex adaptive system of agricultural land and water resources of the Sanjiang Plain and to make evolution analysis of optimized allocation of agricultural land and water resources under different groundwater exploitation plans. This research shows that: with the increased exploitation of groundwater, the agricultural production value and the grain yield have increased; the ecological area has decreased within a certain range; with the increased restriction in groundwater exploitation year by year, the efficiently-used land area will decrease, resulting in a lot of land not being effectively utilized and seriously hindering the coupling between the regional water and land resources and the local economy development.
\end{abstract}

Keywords: Sanjiang Plain, agricultural land and water resources, complex adaptive system

\section{Introduction}

Land and water resources are the core resources of agricultural production [1]-[2] and basic materials that human survival and development rely on, playing an important role in the sustainable development of the region [3]. China has a serious shortage of land and water resources. Along with the increase in population and rapid economic development, the scope and intensity of the use of land and water resources have been increasing, and the disputes in fighting for water between various sections and industries become increasingly acute. As agriculture is a big consumer of land and water resources, the proper allocation of land and water resources of is not only related to the social and economic development, but also affects the ecological environment restoration and reconstruction.

However, the previous researches on the optimized allocation of regional resources usually separate land and water resources as independent systems [4]-[6], lay more emphasis on the water resource system and lack an effective coupling with the land 
resource system, hindering the full overall performance of the regional land and water resource system and easily leading to the system overloaded while running. Therefore, it is necessary to treat land and water resources as a system to make overall optimized allocation to improve the regional land and water resource utilization efficiency, maintain the relative balance of the system, obtain the optimal ecological and economic benefits and achieve sustainable use of land and water resources. Therefore, this research takes the Sanjiang Branch of Heilongjiang Land Reclamation Bureau as an example, treats agricultural land and water resources as a complex adaptive system and make its complex adaptive allocation, so as to provide an important reference for improving the regional agricultural land and water resource utilization efficiency, obtaining higher grain production efficiency and achieving the sustainable use of agricultural land and water resources.

\section{Establishment of Complex Adaptive Allocation Model}

\subsection{Government Subject}

The regional government is the controller of the entire region and its ultimate optimization objectives have more than one, which means the adaptability of the government subject is shown by the description of a multi-objective problem. The government subject's adaptability in this model is shown by maximum regional comprehensive benefits; the comprehensive benefits of this model is a single objective that is obtained after the processing of agricultural benefit objective and ecological benefit objective by utility function through the multi-objective analysis method, and that can be used to make a comprehensive evaluation of the system state. The agricultural benefit objective results from the equilibrium between the grain yield objective and the agricultural income objective or, specifically a government's comprehensive benefit objective resulting from the non-dimensionalization of two utility functions:

$$
\begin{gathered}
E C O S=\frac{E C O A-E C O A M I N}{E C S O M A X-E C O A M I N} \quad Y=\frac{Y A-Y S M I N}{Y S M A X-Y S M I N} \quad M=\frac{M A-M A M I N}{M A M A X-M A M I N} \\
A W E L=f(Y S, M S) \quad S W E=L f(A W E \text { E } \mathbb{E} C O) !
\end{gathered}
$$

ECOA and ECOS respectively mean standard ecological area $\left(\mathrm{hm}^{2}\right)$ and nondimensionalized standard ecological area; $Y$ and YS respectively mean grain yield $(t)$ and non-dimensionalized grain yield; $M$ and MS respectively mean agricultural production value (RMB) and non-dimensionalized agricultural output value; ECOAMAX means the threshold value of

Maximum standard ecological area $\left(\mathrm{hm}^{2}\right)$; ECOAMIN means the threshold value of minimum standard ecological area $\left(\mathrm{hm}^{2}\right)$; YMAX means maximum grain yield $(\mathrm{t})$; YMIN means minimum grain yield $(\mathrm{t})$; MMAX means maximum grain production value (RMB); MMIN means the minimum grain production value (RMB); AWEL means agricultural benefits; SWEL means comprehensive benefits; f means utility function. 


\subsection{Agricultural Production Subject}

As a sector-level subject, its adaptability is shown by maximum comprehensive benefits of the agricultural sector, including pursuit of grain yield and agricultural production value, and is also a multi-objective problem.

Calculation of grain yield:

$$
Y=y_{j} \bullet s_{j}
$$

Where $\mathrm{Y}$ means gross grain yield $(\mathrm{t})$, yield per unit area of the $\mathrm{j}-\mathrm{th}$ crop $\left(\mathrm{t} / \mathrm{hm}^{2}\right)$, $\mathrm{j}$-th crop planting area $\left(\mathrm{hm}^{2}\right)$ and $\mathrm{j}=\left(\begin{array}{lll}1 & \ldots & 6\end{array}\right)$ six kinds of crops in the agricultural sector.

Calculation of economic benefits:

$$
M=\sum_{j=1}^{6} Y_{j} \bullet P_{j}
$$

Where M means agricultural income (RMB), yield of the $\mathrm{j}$-th crop and unit price of the $\mathrm{j}$-th $\operatorname{crop}(\mathrm{RMB} / \mathrm{t})$.

\subsection{Ecological Subject}

As a sector-level subject, its adaptability is shown by maximum comprehensive benefits of the ecological sector. This research uses standard ecological area to measure the benefits of the ecological sector. The ecological footprint method [7] is used to cover different ecological types into standard ecological areas through "equivalency factors". This research set the yield factor to 1 and equilibrium factors of pasture, woodland and waters to $0.5,1.1$ and 0.2 respectively which are respectively multiplied by the actual areas to be standard ecological areas.

Standard ecological area:

$$
S_{E C O}=\sum_{i=1}^{3} \text { 因子 } \bullet a_{i}
$$

Where means standard ecological area, the $i$-th ecological area and $i=(1 \ldots 3)$ three ecological types.

\section{Model Solving and Analyzing}

\subsection{Establishment of Boundary Conditions}

The raw data come from the Statistical Yearbook of Sanjiang Branch and statistics of water conservation construction in Heilongjiang Province. The data of the sector and the ecological sector of the Sanjiang Branch of Heilongjiang Land Reclamation Bureau in 2008 is show in Table 1 and Table 2 respectively, and the model constraints, as shown in Table 3, are calculated from the data of various years by a certain percentage. The model is initialized by the following data with the establishment of relevant boundary conditions and constraints. 
Table 1. Relevant Data of Agricultural Sector

\begin{tabular}{ccccccc}
\hline Crop Type & Rice & Wheat & Corn & Barley & Bean & Oil Crops \\
\hline $\begin{array}{c}\text { Sowing area } \\
\left(10^{4} \mathrm{hm}^{2}\right)\end{array}$ & 44.91 & 0.47 & 3.62 & 1.80 & 8.46 & 0.68 \\
$\begin{array}{c}\text { Yield per unit area } \\
\left(\mathrm{t} / \mathrm{hm}^{2}\right)\end{array}$ & 8.93 & 5.25 & 7.71 & 5.25 & 2.37 & 1.05 \\
$\begin{array}{c}\text { Production value per } \\
\text { unit area }\left(\mathrm{RMB} / \mathrm{hm}^{2}\right)\end{array}$ & 7815 & 3600 & 5325 & 4000 & 4170 & 5625 \\
$\quad \begin{array}{c}\text { Yield }\left(10^{4} \mathrm{t}\right) \\
\begin{array}{c}\text { Production value } \\
\left(\mathrm{RMB} 10^{8}\right)\end{array}\end{array}$ & 400.93 & 2.44 & 27.88 & 9.47 & 20.11 & 0.71 \\
$\begin{array}{c}\text { Irrigation quota } \\
\left(\mathrm{m}^{3} / \mathrm{hm}^{2}\right)\end{array}$ & 71.29 & 0.37 & 2.90 & 1.53 & 6.66 & 0.56 \\
\hline
\end{tabular}

Table 2. Relevant Data of Ecological Sector

\begin{tabular}{cccc}
\hline Ecological Type & Forest & Pasture & Waters \\
\hline Area $\left(10^{4} \mathrm{hm}^{2}\right)$ & 16.61 & 2.35 & 4.75 \\
Irrigation quota $\left(\mathrm{m}^{3} / \mathrm{hm}^{2}\right)$ & 150 & 3000 & 0 \\
Equilibrium factor & 1.1 & 0.5 & 0.2 \\
\hline
\end{tabular}

Table 3. Boundary Conditions and Constraints

\begin{tabular}{cccccc}
\hline $\begin{array}{c}\text { Constrain } \\
\text { name }\end{array}$ & $\begin{array}{c}\text { Threshold } \\
\text { value of crop } \\
\text { sowing area }\end{array}$ & $\begin{array}{c}\text { Threshold } \\
\text { value of } \\
\text { ecological } \\
\text { area }\end{array}$ & $\begin{array}{c}\text { Groundwater } \\
\text { exploitation } \\
\left(108 \mathrm{~m}^{3}\right)\end{array}$ & $\begin{array}{c}\text { Reclaimable } \\
\text { wasteland } \\
\left(104 \mathrm{hm}^{2}\right)\end{array}$ & $\begin{array}{c}\text { Annual } \\
\text { precipitation } \\
(\mathrm{mm})\end{array}$ \\
\hline Value & $\begin{array}{c}50 \% \text { to } 150 \% \\
\text { of actual area }\end{array}$ & $\begin{array}{c}50 \% \text { to } 150 \% \\
\text { of actual area }\end{array}$ & 23.93 & 7.45 & 6342 \\
\hline
\end{tabular}

\subsection{Result Analysis}

The Sanjiang Branch has $800000 \mathrm{hm}^{2}$ of utilizable agricultural and ecological land. As the region mainly uses groundwater to irrigate, the evolution analysis of optimized allocation of agricultural land and water resources in the region under different groundwater exploitation programs is made as follows. See Table 4 for program numbers and Table 5 and Table 6 for specific water quantity allocation programs and planting structure programs.

Table 4. Groundwater Exploitation of Different Programs

\begin{tabular}{ccccccccccc}
\hline $\begin{array}{c}\text { Program } \\
\text { number }\end{array}$ & 1 & 2 & 3 & 4 & 5 & 6 & 7 & 8 & 9 & 10 \\
\hline $\begin{array}{c}\text { Groundwater } \\
\text { exploitation } \\
\left(10^{8} \mathrm{~m}^{3}\right)\end{array}$ & 23.80 & 23.50 & 23.00 & 22.47 & 21.64 & 21.19 & 20.94 & 20.36 & 19.90 & 19.47 \\
\hline
\end{tabular}


Table 5. Water Resource Allocation Program

\begin{tabular}{ccccccccccc}
\hline Program & 1 & 2 & 3 & 4 & 5 & 6 & 7 & 8 & 9 & 10 \\
\hline $\begin{array}{c}\text { Agriculture } \\
\left(10^{8} \mathrm{~m}^{3}\right)\end{array}$ & 23.05 & 22.77 & 22.19 & 21.72 & 20.94 & 20.46 & 20.13 & 19.65 & 19.16 & 18.84 \\
$\begin{array}{c}\text { Ecology } \\
\left(10^{8} \mathrm{~m}^{3}\right)\end{array}$ & 0.74 & 0.73 & 0.79 & 0.75 & 0.70 & 0.74 & 0.81 & 0.71 & 0.74 & 0.63 \\
\hline
\end{tabular}

As can be seen from Table 6, with the reduction in groundwater exploitation, the planting area of rice which consumes more water decreases gradually, the planting area of oil crops which consumes more water but have better economic benefits has no great fluctuation, and the planting areas of other crops which consume less water change within a certain range with no great reduction in the overall sowing areas.

With the actual water consumption in 2008 as the benchmark and other constraints unchanged, simulation calculation is made for each program to obtain the respective relationships between groundwater exploitation and agricultural production value, grain yield, standard ecological area and efficiently-utilized land area, as shown in Figures 3 to 6 .

Table 6. Planting Structure Adjustment Program

\begin{tabular}{cccccccccc}
\hline Program & Rice & Wheat & Corn & Barley & Bean & $\begin{array}{c}\text { Oil } \\
\text { Crop }\end{array}$ & Forest & Pasture & Waters \\
\hline 1 & 44.27 & 0.06 & 2.69 & 0.42 & 3.15 & 0.57 & 22.32 & 1.34 & 2.55 \\
2 & 43.78 & 0.06 & 2.80 & 0.37 & 2.85 & 0.47 & 21.86 & 1.34 & 2.46 \\
3 & 42.46 & 0.05 & 3.12 & 0.47 & 2.94 & 0.61 & 20.71 & 1.60 & 2.57 \\
4 & 41.69 & 0.06 & 2.56 & 0.36 & 3.11 & 0.48 & 19.15 & 1.54 & 2.44 \\
5 & 40.00 & 0.06 & 3.03 & 0.34 & 3.01 & 0.55 & 19.85 & 1.34 & 2.39 \\
6 & 39.05 & 0.06 & 2.94 & 0.35 & 3.06 & 0.54 & 19.86 & 1.47 & 2.53 \\
7 & 38.63 & 0.06 & 2.24 & 0.37 & 2.89 & 0.50 & 19.63 & 1.71 & 2.48 \\
8 & 37.44 & 0.06 & 2.75 & 0.46 & 2.94 & 0.70 & 19.26 & 1.42 & 2.43 \\
9 & 36.61 & 0.05 & 2.50 & 0.43 & 2.89 & 0.53 & 17.27 & 1.61 & 2.44 \\
10 & 35.89 & 0.06 & 2.67 & 0.44 & 2.85 & 0.64 & 16.96 & 1.25 & 2.44 \\
\hline
\end{tabular}

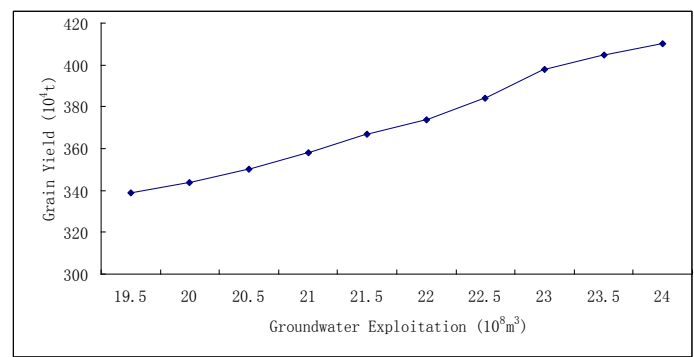

Fig. 1. Relationships between Groundwater Exploitation and Grain Yield 


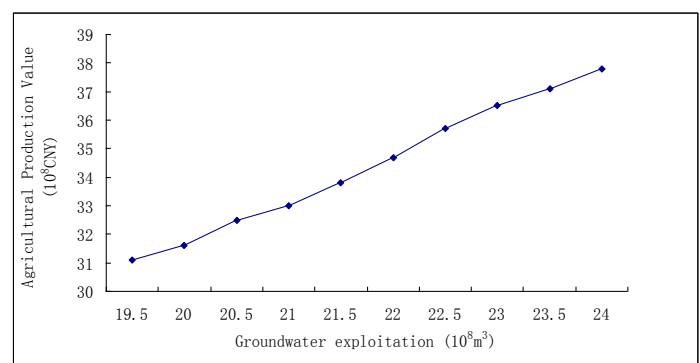

Fig. 2. Relationships between Groundwater Exploitation Agricultural Production Value

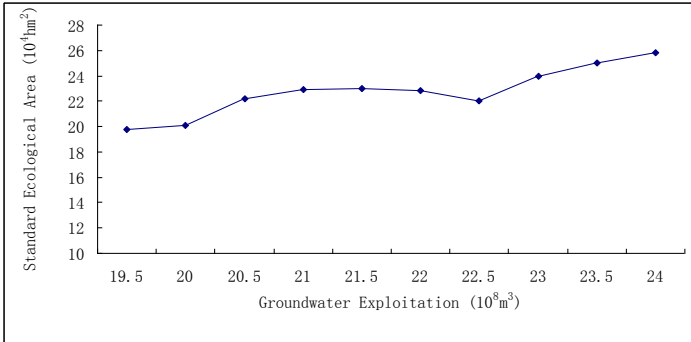

Fig. 3. Relationships between Groundwater Exploitation and Standard Ecological Area

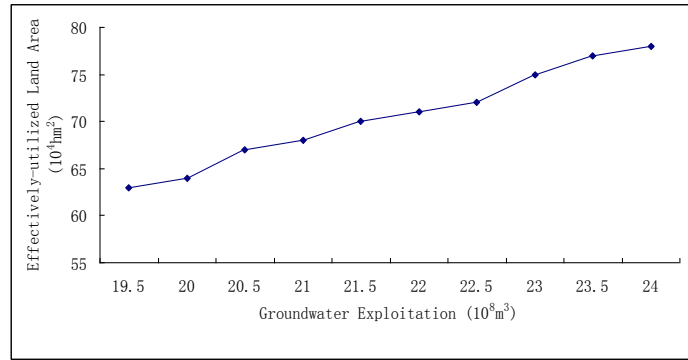

Fig. 4. Relationships between Groundwater Exploitation and Standard Ecological Area

As can be seen from Figure 2 and Figure 3, with the increase in groundwater exploitation, agricultural production value and grain yield have also increased. According to Figure 4, ecological area decreases within a certain range, mainly because the ecological development is restricted and the effect is high when the groundwater exploitation is smaller, and the effect will decrease when the restriction decreases with the increase in exploitation. This nonlinear relationship and the different sensitivity of various subsystems to changes in water quantity show the adaptability. According to Figure 5, with the increased restriction in groundwater exploitation year by year, the efficiently-used land area will decrease, resulting in a lot of land not being effectively utilized and seriously hindering the coupling between the regional water and land resources and the local economy development. 


\section{Conclusions}

According to the characteristics of the agricultural land and water resources of the Sanjiang Plain, this research treat agricultural land and water resources as a complex adaptive system and use the theory of complex adaptive system to put forward an allocation model of the complex adaptive system of agricultural land and water resources of the Sanjiang Plain and to make evolution analysis of optimized allocation of agricultural land and water resources under different groundwater exploitation plans. The evolution analysis has showed that water resources have become a bottleneck restricting the Sanjiang Plain's coordinated economic, social and ecological development. The development and utilization of surface water, groundwater protection and construction of water conservancy projects become effective means to solve the aforementioned problem. This research has important theoretical and practical significance for the development and utilization of agricultural land and water resources of the Sanjiang Plain and the coordinated economic, social, and ecological development.

\section{Acknowledgment}

The author would like to thank his collaborators from and support of Natural Science Foundation of China (NO. 51179032、NO. 51279031、NO. 51109036), Ministry of water resources public welfare industry special funds for scientific research project (NO. 201301096), The ministry of education in the new century excellent talents to support plan, Province Natural Science Foundation of Heilongjiang (No: E201241), New Century Talent Supporting Project by Education Ministry, The Yangtze River Scholars Support Program of Colleges and Universities in Heilongjiang Province, Heilongjiang Province Water Conservancy Science and Technology project (No: 201318), Prominent young person of Heilongjiang Province(JC201402).

\section{References}

1. Liu Changming, Sun Rui. Ecological Aspects of Water Cycle: Progress in the Research on the Water and Energy Balance of the Soil-Vegetation-Atmosphere System [J]. Advances in Water Science, 1999, 10(3): 251-259 (in Chinese)

2. Jiang Qiuxiang, Fu Qiang, Wang Zilong et al. Space Matching Pattern of the Sanjiang Plain's Land and Water Resources [J]. Journal of Natural Resources, 2011, 26(2):270-277 (in Chinese)

3. Li Tianxiao, Fu Qiang, Peng Shengmin. DPSIR-based Evaluation on the Carrying Capacity of Land and Water Resources [J]. Journal of Northeast Agricultural University, 2012, 43(8):128-134 (in Chinese)

4. Sand Jinxia, Liu Bin, Xie Xinmin et al. Research on the Optimized Allocation of Water Resources Based on Particle Swarm Optimization [J]. Hydroelectric Energy Science, 2012, 30(9):33-35, 69 (in Chinese) 
5. Chen Xiaonan, Duan Chunqing, Qiu Lin et al. Application of Particle Swarm-based Large System Optimization Model in the Optimized Allocation of Water Resources in Irrigation Areas [J]. Transactions of the CSAE, 2008, 24(3):103-106 (in Chinese)

6. Dong Pinjie, Lai Hongsong. Optimized Allocation of Spatial Structure of Land Use Based on Multi-objective Genetic Algorithm [J]. Geography and Geo-Information Science, 2003, 19(6): 52-55 (in Chinese)

7. Zhang Jun, Zhang Ren Zhi, Zhou Dongmei. Evaluation of the Water Resources Carrying Capacity of Shule River Basin Based on Ecological Footprint [J]. Pratacultural Science, 2012, 21(4): 267-274 (in Chinese)

8. Fu Qiang, Wang Kai, Ren Shoude. Real-coded and Multi-objective Nested Accelerating Genetic Algorithm Based on Complex System Evolution Optimization [J]. System Engineering Theory and Practice, 2012, 32(12): 2718-2723 (in Chinese) 